\title{
PSYCHE.
}

\section{THE SPECIES OF NEMOBIUS FOUND IN NORTH AMERICA.}

\author{
BY SAMUEL H. SCUDDER, CAMBRIDGE, MASS.
}

In the Journal of the New York three additional new species, in deEntomological Society for September, scribing which at this time I remodel I896 (Vol. iv, pp. 99-107), I published the earlier part of the table, and puba paper on "'The North American lish it in a complete form, so as to inspecies of Nemobius," describing eight clude all the species. Professor Bruner new species and giving a table for the also sends me an additional species, separation of the fifteen known species. apparently new, from Vera Cruz, but After the printing but before the publi- as it is only represented by a male, cation of the paper, and, therefore, too I refrain from describing it until the late for insertion therein, I received female is found; it seems to be allied to from Professors Bruner and Cockerell N. cubensis.

\section{Table to determine the N. A. Species of Nemobius.}

$\mathrm{A}^{1}$. Ovipositor as long as or slightly (rarely as much as one-sixth) shorter than the hind femora, generally rigidly straight.

$b^{1}$. Tip of ovipositor unarmed; last joint of maxillary palpi very obliquely excised at apex.

$c^{1}$. Tegmina short; wings wanting; last joint of maxillary palpi bicolored, the oblique apical excision of lower margin beginning before the middle. . . $\quad$. $\quad$. $\quad . \quad$. . distinguendus. $c^{2}$. Tegmina long; wings very long; the oblique apical excision of lower margin of maxillary palpi beginning at or beyond the middle.

$\mathrm{d}^{1}$. Smaller, darker form; last joint of maxillary palpi bicolored, the oblique apical excision of lower margin beginning at the middle; tegmina scarcely longer than head and pronotum together; blade of ovipositor relatively short, its lower margin straight delicatus. $\mathrm{d}^{2}$. Larger, lighter forms ; last joint of maxillary palpi unicolored, the oblique apical excision beginning beyond the middle ; tegmina much longer than head and pronotum together; blade of ovipositor relatively long, its lower margin arcuate.

$\mathrm{e}^{1}$. Head and pronotum uniform fuscous. . . ensifer.

$\mathrm{e}^{2}$. Head and pronotum luteous, conspicuously variegated with fuscous. . . . . . . . . pictus. 
$b^{2}$. Tip of ovipositor serrate or dentate; last joint of maxillary palpi almost transversely excised at apex.

$c^{1}$. Ovipositor distinctly (at least a tenth) longer than hind femora. $d^{1}$. Blackish; dark and light colors of tegmina of $q$ feebly contrasted longitudinally above (Northern) . . . fasciatus. $\mathrm{d}^{2}$. Grayish; dark and light colors of tegmina of $\$$ strongly contrasted longitudinally above as on sides (Southern) . canus.

$\mathrm{c}^{2}$. Ovipositor barely as long as, or slightly shorter than; hind femora. $\mathrm{d}^{1}$. Pronotum distinctly tapering, fully twice as broad posteriorly as long; teeth of ovipositor exceptionally fine. . . melleus. $\mathrm{d}^{2}$. Pronotum scarcely tapering, less than twice as broad posteriorly as long; teeth of ovipositor relatively coarse.

$\mathrm{e}^{\mathrm{J}}$. Teeth of ovipositor blunt, little elevated; wings generally very long. • . . . . . . . . socius. $\mathrm{e}^{2}$. Teeth of ovipositor sharp, well elevated, well separated; wings wanting.

$f^{1}$. Te̊gmina of $q$ nearly or quite twice as long as pronotuin ; of $\delta$ strongly rounded apically, feebly margined with pallid at sides of dorsal field only, if at all utahensis. $\mathrm{f}^{2}$. Tegmina of $q$ scarcely longer than pronotum; of $\delta$ broadly rounded apically, with the dorsal field distinctly margined with pallid throughout except at base.

ambitiosus.

$\mathbf{A}^{2}$. Ovipositor distinctly (at least one-fourth) shorter than the hind femora, usually a little arcuate.

$b^{1}$. Tegmina of $q$ nearly or quite as long as the abdomen; wings generally twice as long as tegmina.

$c^{1}$. Ovipositor no longer, or scarcely longer, than head and pronotum together.

$d^{1}$. Face without vertical pale stripes; lateral field of $q$ tegmina tapering only on the apical third, subequal before it.

neomexicanus.

$d^{2}$. Face with a pair of narrow, vertical, percurrent, pale stripes next the inner margin of the eyes; lateral field of $q$ tegmina regularly tapering almost from the base. . . . trinitatis.

$c^{2}$. Ovipositor distinctly longer than head and pronotum together. $\mathrm{d}^{1}$. Tegmina of $q$ apically truncate, a little shorter than the abdomen; wings wanting . . . . . aterrimus. $d^{2}$. Tegmina of $q$ apically rounded, as long as the abdomen; wings generally present and then very long. . . . cubensis. 
$b^{2}$. Tegmina of $q$ much shorter than the abdomen; wings wanting.

$c^{1}$ Ovipositor barely arcuate.

$d^{1}$. Tegmina of $q$ no longer than head and pronotum combined.

mormonius.

$d^{2}$. Tegmina of $q$ distinctly longer than head and pronotum combined.

$\mathrm{e}^{1}$. Longitudinal markings of head continuous to extreme back of same; ovipositor with distinct and well separated teeth at apex. . . . . . . . . toltecus. $\mathrm{e}^{2}$. Longitudinal markings of head interrupted at the crown, the whole back portion immaculate, sharply defined from the portions in front at the summit, which is feebly subcarinate transversely; ovipositor with fine, close, minute denticulations.

$c^{2}$. Ovipositor distinctly though but feebly arcuate.

mexicanus. carolinus

N. delicatus sp. nov. Head piceous marked by a slencier longitudinal luteous stripe on either side next the eye and extending from the antennal scrobes to the back of the head, sometimes accompanied by a pair of shorter dorsal stripes posteriorly; without bristles; eyes moderate, rather prominent; antennae dark fuscous; maxillary palpi pale luteous, the outer side of the antepenultimate joint and more than the apical half of the last joint dark fuscous, the latter bent in the middle where the oblique apical excision begins. Pronotum equal, slightly less than twice as broad as long, blackish fuscous, glistening, rather sparsely beset with not very long black bristles. Tegmina reaching scarcely beyond the middle of the abdomen, apically rounded, more broadly in the $q$ than in the $\delta$, infumated or testaceous, the upper portion of the lateral field narrowly and the inner border of the dorsal field broadly dark fuscous; wings very long, reaching in the $q$ the tip of the ovipositor. Legs fuscous, more or less luteo-testaceous beneath. Cerci delicately tapering, a little shorter than the ovipositor in the $\$$. Ovipositor straight except for a slight basal bend, a little longer than the hind femora, the apical blades rather small, slightly enlarged at the base, with straight inferior margin, unarmed. Length of body, $\delta, 8 \mathrm{~mm} ., 9,8.75 \mathrm{~mm}$. ; of hind femora, $\delta$, $5.5 \mathrm{~mm}$., \%, $6 \mathrm{~mm}$.; of ovipositor, $6.9 \mathrm{~mm}$.

$2 \delta, 2 \&$, San Rafael, Vera Cruz, Mexico, Townsend (L. Bruner).

N. pictus sp. nov. Head rather prominent anteriorly, luteous, heavily marked with blackish fuscous above, which does not reach the eyes and is broken by a pair of obliquely longitudinal, narrow, luteous dashes on either side, the outer more posterior, more oblique, and open in front toward the eyes; clypeus infuscated; eyes not very large, very full and prominent; antennae luteous ; maxillary palpi luteous, the last joint feebly and narrowly infuscated at extreme tip, the very oblique apical excision beginning well beyond the middle. Pronotum equal, less than twice as broad as long, dull luteous, obscurely and broadly fuscous in the middle of either side of the disk and having an impressed crescentic darker spot, sharply margined with black, opening forward on either side just before the middle; without bristles except along the front and hind margins and there short. Tegmina scarcely exceeding the middle of the abdomen, dull 
luteous, the veins and the middle of the cells more or less infuscated and the outer margins of the dorsal field black between the veins; wings very long. Legs luteous, the hind femora dotted with fuscous exteriorly. Ovipositor somewhat longer than the hind femora, straight, the apical blades long and tapering, scarcely enlarged basally, unarmed. Length of body, $125 \mathrm{~mm}$. ; of hind femora, $8.25 \mathrm{~mm}$.; of ovipositor, $9 \mathrm{~mm}$.

I $q$, Colorado in New Mexico, T. D. A. Cockerell, B. 59 .

N. melleus sp. nov. Dull luteous. Head feebly infuscated above, clothed with sparse black bristles, and with three short longitudinal fuscous stripes posteriorly; eyes rather prominent; antennae luteous, feebly infuscated; maxillary palpi luteous, the last joint infuscated only at extreme transversely truncate tip. Pronotum very sparsely beset with black bristles, transverse, tapering rapidly, posteriorly fully twice as broad as long, the incisures fuscous, two small, transverse, oval, fuscous spots in the middle of either side of the disk posteriorly. Tegmina nearly as long as the abdomen, luteous, but infumated basally along the inner margin; wings more than twice as long as the tegmina. Legs luteous, the hind femora feebly and obscurely infuscated. Cerci slender, reaching to beyond the middle of the ovipositor. Ovipositor straight, a little longer than the tegmina and a little shorter than the hind femora, castaneous, the apical blades black, slightly enlarged basally, beyond tapering regularly to a fine point, the teeth exceptionally minute and crowded. Length of body, II.5 mm.; of hind femora, $8 \mathrm{~mm}$.; of ovipositor, 7.1 $\mathrm{mm}$.

I + , San Rafael, Vera Cruz, Mexico, Townsend (L. Bruner).

\section{NOTES ON THE WINTER INSECT FAUNA OF VIGO COUNTY, INDIANA.- VII.}

BY W. S. BLATCHLEY, INDIANAPOLIS, INDIANA.

\section{COLEOPTERA (Cont.).}

\section{Elateridae.}

Fifty-three species of this family are known to occur in the county. Representatives of but twelve of these have been taken during the winter months, as follows :

184, Adelocera discoidea Web. On several occasions in winter beneath loose bark of logs. An uncommon species.

185 , Lacon rectangularis Say. Occurs only on a dry sandy hillside where the river terrace meets the old canal.
There it is frequent beneath chips and chunks. Dec. I2. Jan. I.

I86, Cryptohypnus pectoralis Say. One specimen only from the county. Jan. 7, beneath chunk.

I87, C. obliquatulus Melsh. Frequent in winter beneath logs on sandy hillsides.

I88, Monocepedius auritus Hbst. Very common in winter beneath logs and mullein leaves on sandy hillsides. Varies from reddish-brown with black markings to deep black, three distinct color forms occurring. Usually two or three hibernate together. 

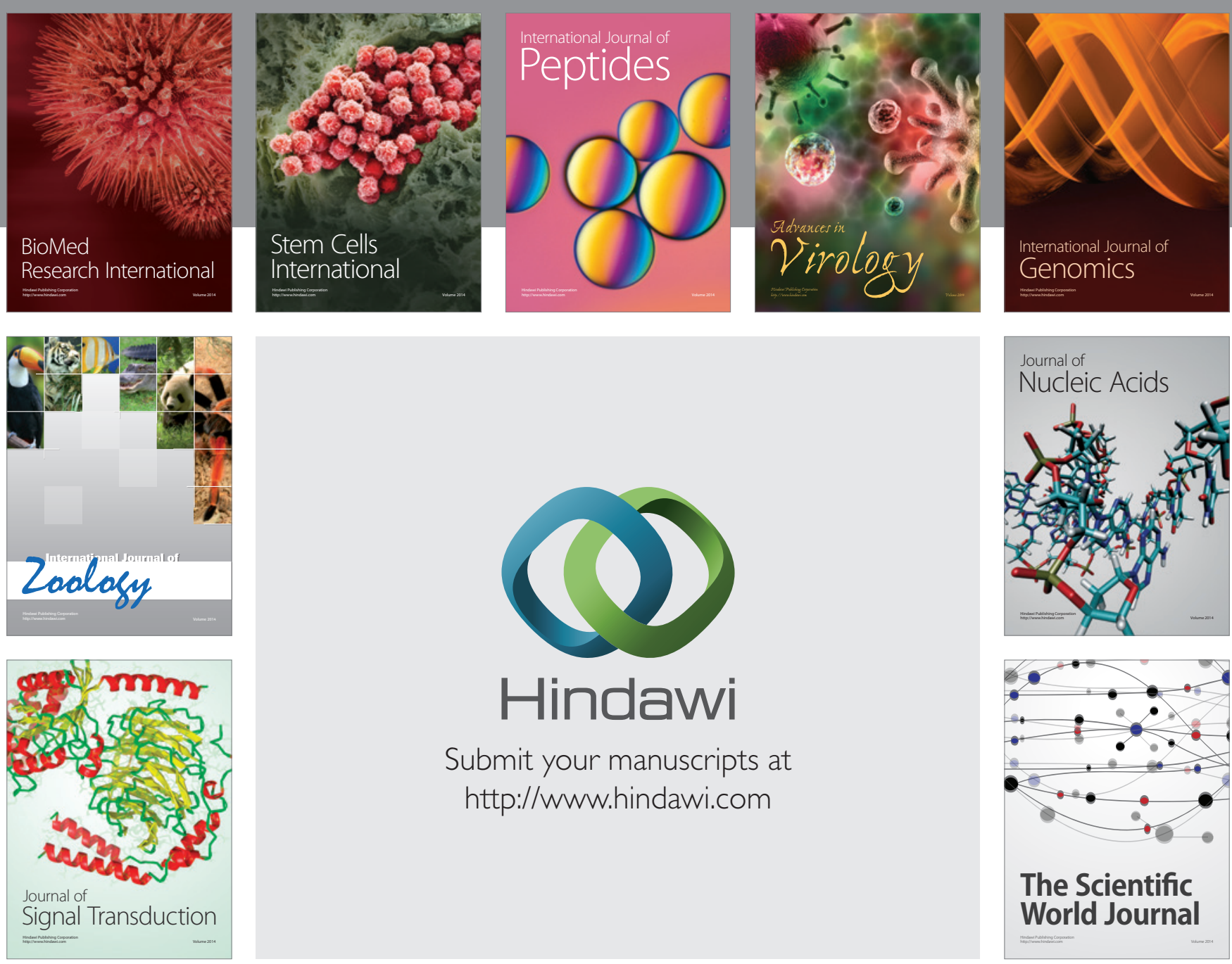

Submit your manuscripts at

http://www.hindawi.com
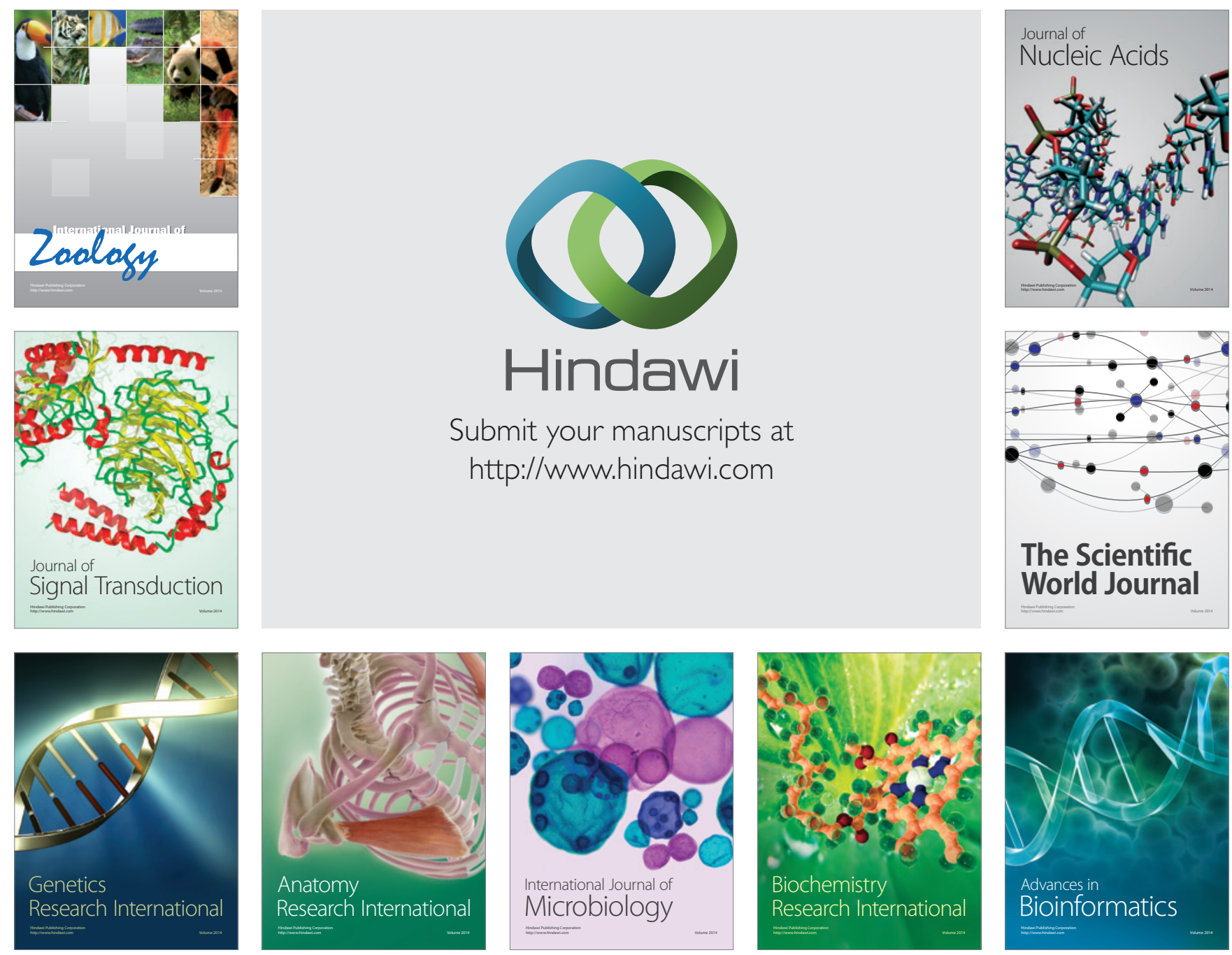

The Scientific World Journal
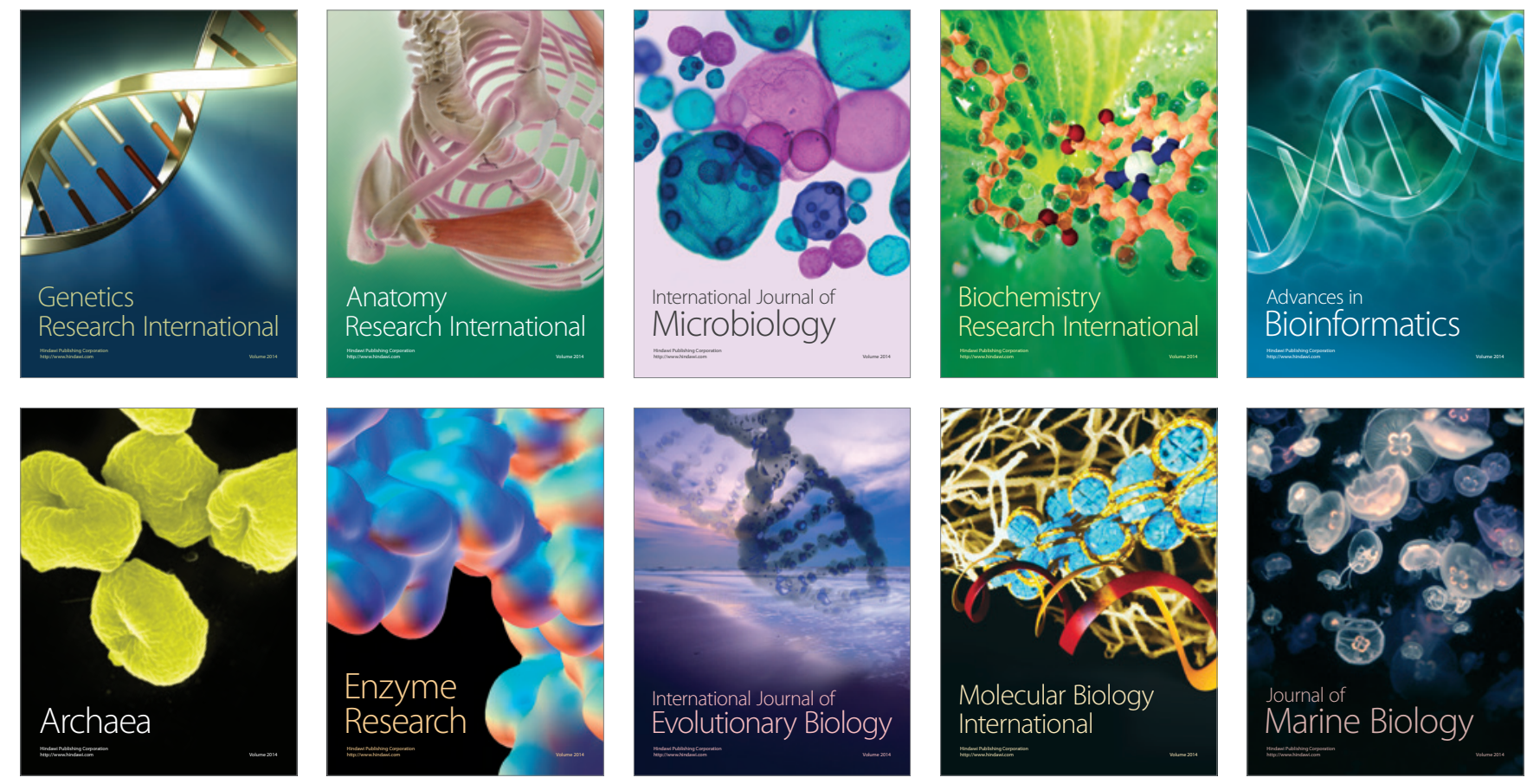